\title{
Pituitary apoplexy after hypo-fractionated stereotactic radiotherapy
}

\author{
Geetika Bhatt ${ }^{1}$, Aashish D. Bhatt ${ }^{2}$, Craig L. Silverman ${ }^{3}$, Anthony E. Dragun ${ }^{3}$ \\ 1. Department of Internal Medicine, University of Louisville, KY, USA. 2. Department of Radiation Oncology, Massachusetts \\ General Hospital, Boston, MA, USA. 3. Department of Radiation Oncology, University of Louisville, KY, USA
}

Correspondence: Aashish D. Bhatt. Address: 305, Highwood drive, Louisville, KY, 40206, USA.

E-mail: aashbhatt@gmail.com

Received: March 6, 2013

DOI : $10.5430 /$ jst.v3n3p22

Accepted: March 20, 2013

Online Published: March 26, 2013

URL: http://dx.doi.org/10.5430/jst.v3n3p22

\section{Abstract}

Introduction: Pituitary apoplexy is a rare phenomenon in pituitary adenomas. We present a case of pituitary apoplexy that developed shortly after hypo-fractionated stereotactic radiotherapy (HF-SRT) for a pituitary adenoma. To our knowledge there is no prior report of pituitary apoplexy following stereotactic radiotherapy.

Case report: A 67 year old female initially presented with visual abnormalities. Workup then revealed a large sellar mass. She underwent a trans-sphenoidal resection then with pathology demonstrating a non-secretory pituitary adenoma. Her vision returned to normal after the resection. Five years later, follow-up MRI showed evidence of recurrence. The size of the lesion and its proximity to the optic apparatus were not considered adequate for a single fraction stereotactic radiosurgery (SRS). Based on this, HF-SRT was recommended as an alternative to re-operation. The tumor was treated to a dose of 4,000 cGy given at 400 cGy per fraction. Two months later, the patient presented with visual impairment and ocular palsies. She was diagnosed to have pituitary apoplexy. Although spontaneous tumor apoplexy cannot be excluded, a causal role for radiotherapy is hypothesized.

Conclusion: Radiotherapy as a cause of pituitary apoplexy is not well understood or documented. Pituitary apoplexy should be suspected in a patient who develops new onset headaches and visual disturbance during or shortly after radiotherapy. Rapid diagnosis of pituitary apoplexy allows for aggressive management and neurosurgical decompression which decreases mortality and morbidity.

\section{Key words}

Pituitary adenoma, Pituitary apoplexy, Stereotactic radiotherapy

\section{Introduction}

Pituitary apoplexy is a rare and life threatening condition with an incidence of $0.6 \%$ to $27.7 \%$ that usually results from a sudden hemorrhage or infarction-induced swelling, often within a pre-existing pituitary adenoma ${ }^{[1-3]}$. The clinical syndrome of apoplexy is characterized by a variety of symptoms including; sudden headache (97\%), nausea (80\%), visual impairment (71\%), opthalmoplegia (78\%), hypertension (26\%), impaired consciousness and hormonal dysfunction ${ }^{[4]}$. Signs of meningeal irritation are rare but can be present at presentation ${ }^{[5,6]}$. MR imaging reveals hemorrhage more often than CT imaging and is the modality of choice ${ }^{[4]}$. 
Although the condition can occur spontaneously, many predisposing factors have been implicated in the literature. Head trauma ${ }^{[7,8]}$, bromocriptine therapy or withdrawal ${ }^{[9,10]}$, anticoagulation ${ }^{[11]}$, pregnancy- Sheehan's syndrome, cardiac bypass ${ }^{[12,13]}$, bowel or other general surgery ${ }^{[14]}$, atherosclerosis, diabetic ketoacidosis ${ }^{[15]}$, estrogen therapy ${ }^{[16]}$, hypertension ${ }^{[17,18]}$ and hypotension have been cited as inciting events. Radiation therapy has also been implicated as a possible inciting event ${ }^{[19-21]}$.

\section{Case presentation}

A 67 year old female, with a past medical history of hypertension, initially presented with complaints of visual abnormalities in late 2004. A full workup was done which revealed a large sellar mass with evidence of pituitary hemorrhage. She underwent a trans-sphenoidal resection then with pathology demonstrating a non-secretory pituitary adenoma. Her vision returned to normal after the resection. Yearly MRI scans of brain were performed which demonstrated a residual sellar mass which remained unchanged. In 2009 (5 years later), MRI showed an increase in size of the lesion, now measuring $2 \times 2.5 \times 2.1 \mathrm{~cm}$. Tumor did not involve the optic chiasm but its most superior portion was right below the chiasm. She was re-evaluated by her neurosurgeon and was referred to Radiation Oncology to discuss non-invasive options for her likely recurrence. Patient had no new pituitary insufficiency symptoms, headache, visual abnormalities or facial numbness at presentation. Recent visual field analysis was normal.

Figure 1. Radiotherapy Plan

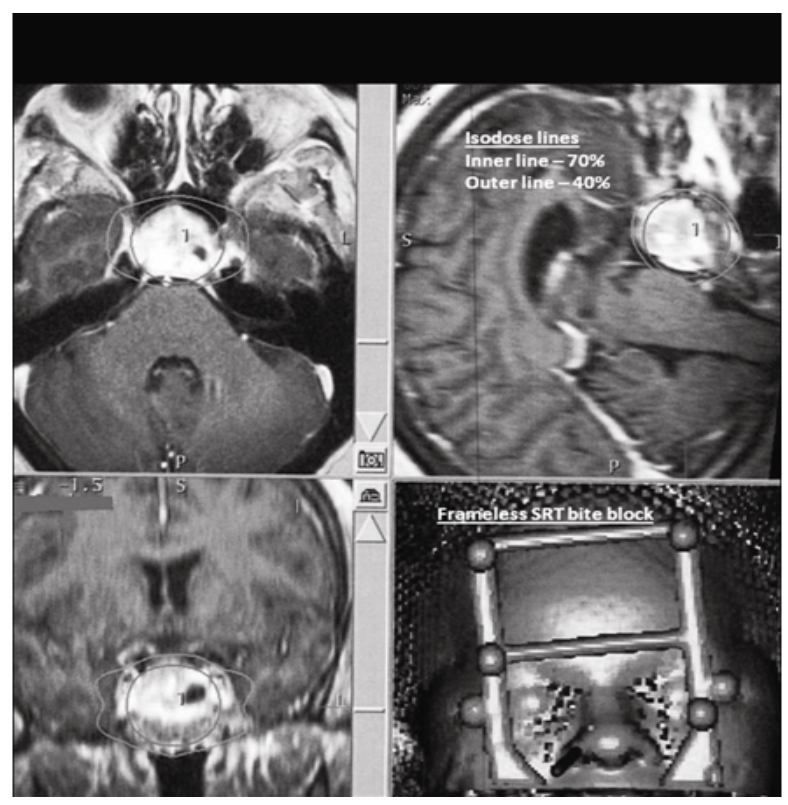

\subsection{Radiotherapy technique}

The size of the lesion and its proximity to the optic apparatus were not considered adequate for a single fraction Stereotactic radiosurgery (SRS). Based on this, either conventional or hypo-fractionated stereotactic radiotherapy (HF-SRT) approach was recommended as an alternative to re-operation. Patient elected to undergo HF-SRT. Initial CT-simulation with MRI fusion was performed for treatment planning using a custom thermoplastic head frame for immobilization and mouth-piece bite-block fitting to deliver frameless stereotactic radiotherapy technique. CT-MRI fusion revealed a large heterogeneous enhancing predominantly sellar mass measuring $2.7 \times 2.5 \times 2.1 \mathrm{~cm}$ (Figures $1 \& 2 \mathrm{a}$ ). The mass extended into the supra-sellar region and appeared to abut the optic chiasm. It extended laterally in the cavernous sinus bilaterally with no evidence of carotid invasion. The tumor was treated using a cone-based HF-SRT approach to a 
total dose of 4,000 cGy given at 400 cGy per fraction. A mono-isocentric technique was used and the dose was prescribed to the $70 \%$ isodose line using 5 treatment arcs and a $30 \mathrm{~mm}$ collimator (Figure 1). Treatments were delivered twice weekly for 5 weeks to total 10 fractions. The patient did not experience any acute side effects while on treatment and completed therapy without delays.

\subsection{Post-radiation course}

Approximately 2 months after completion of radiotherapy, the patient presented to the emergency room with intermittent progressive headaches for a few days accompanied by a sudden loss of vision. Physical examination revealed altered mental status, decreased visual acuity in both eyes and a left $\mathrm{VI}^{\text {th }}$ cranial nerve palsy. MRI brain revealed a well circumscribed heterogeneously enhancing pituitary mass, measuring $3.2 \times 2.5 \times 2.7 \mathrm{~cm}$ with supra-sellar extension causing upward displacement of the chiasm (Figure 2b). The dorsum sella was eroded and the mass slightly protruded into the pre-pontine cistern abutting the pons. The tumor extended downward occupying the sphenoid sinus and expanded laterally into the medial wall of the cavernous sinus abutting the cavernous carotid bilaterally without signs of vascular encasement. Differential diagnoses considered were hemorrhagic stroke or infarction, pituitary apoplexy, radiation necrosis, tumor progression or meningo-encephalitis. Emergent surgical decompression was indicated to reduce intra-cranial and intra-sellar pressure, and a trans-labial trans-sphenoidal resection was completed without complications. Pathology showed the tumor to be a non-secretory pituitary macroadenoma with focal necrosis and hemorrhage, consistent with pituitary apoplexy. Immediate post-surgical MRI revealed reduction in the size of the pituitary mass, measuring $2.4 \times 1.9 \times 2.3 \mathrm{~cm}$ (Figures 2c \& 2d). On the first post-operative day, the patient had immediate and significant improvement in her visual symptoms. She had a triphasic response with initial diabetes insipidus which normalized after vasopressin therapy. She also developed hypothyroidism. Her endocrine work-up was otherwise normal.

Figure 2. Serial MRI images of pituitary through the course of events

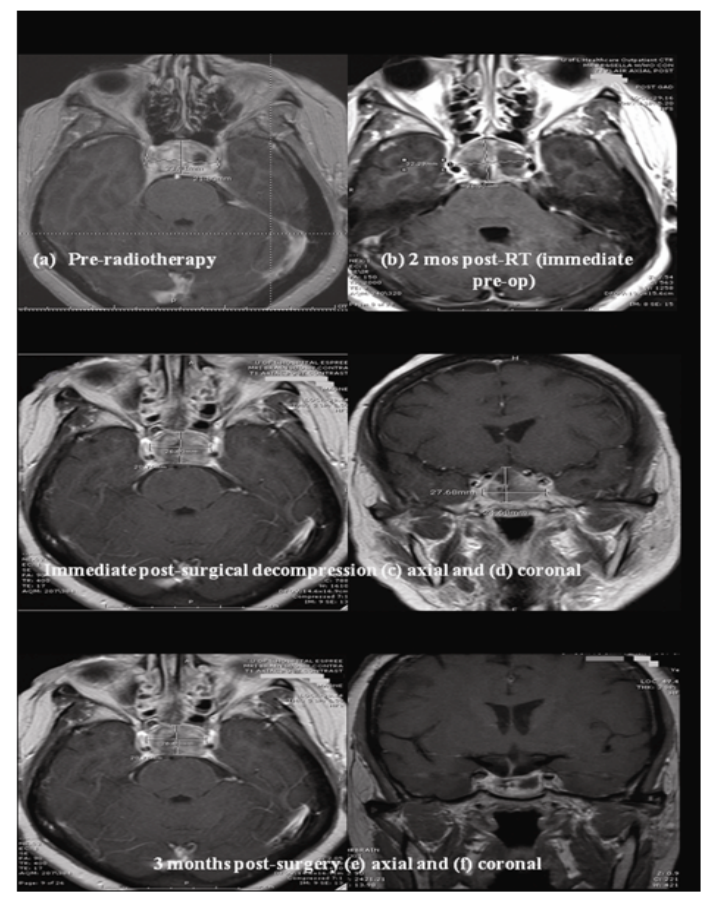

At 3 month follow-up, MRI showed continuous shrinkage in the size of the adenoma with retraction in its cranio-caudal extent (Figures 2e \& 2f). Visual exam revealed slightly improved acuity but persistent left $\mathrm{VI}^{\text {th }}$ nerve palsy, diplopia, and decreased bi-temporal field of vision. 


\section{Discussion}

Pituitary adenomas constitute up to $10 \%$ of all CNS tumors and may be secretory (70\%) or non-secretory (30\%) ${ }^{[22]}$. Secretory adenomas typically present with endocrinopathies, the most common being prolactinomas (50\%). Nonsecretory Adenomas present clinically due to their progressive increase in size and the mass effect exerted on the surrounding tissues, especially the optic apparatus. Therapeutic goals are to normalize the endocrine disturbance, decompression and inhibition of further lesion growth to prevent visual symptoms.

Microsurgery is the gold standard for the treatment of sellar lesions with the advantages of immediate decompression of optic apparatus, pathological confirmation and rapid reduction of hormone levels. Trans-sphenoidal resection is currently the most widely used approach. Trans-cranial approach is used for sellar lesions with extensive supra- or para-sellar extension. Even in the best of hands, however, microsurgery alone provides long-term tumor control rates of only $50 \%-80 \%{ }^{[23,24]}$.

Radiotherapy is an established option in the definitive treatment of pituitary adenomas, especially when tumor size or patient morbidity prohibits surgery ${ }^{[25,26]}$. It can also be administered post-operatively as adjuvant therapy to inhibit recurrent growth, after a sub-total resection or later when clinical symptoms or neuro-imaging findings indicate a recurrence. Local tumor control rates of approximately $90 \%$ after 10 years are achieved with the combination of neurosurgery and postoperative radiotherapy ${ }^{[26,31]}$.

Radiotherapy can be administered using conventionally fractionated (1.8-2.0 Gy/fx), hypo-fractionated (4.0-6.0 Gy/fx) or single fraction radiosurgical (12-15 Gy/fx) techniques. Stereotactic radiosurgery (SRS) has been shown to have the most potent radiobiological effect than other forms of fractionated radiation therapy, as demonstrated by faster normalization of hormone levels in secretory lesions ${ }^{[27,28]}$. For large adenomas or close proximity to the optic apparatus $(<3 \mathrm{~mm})$, fractionated radiotherapy schedules are more appropriate in order to minimize the risk of acute and late toxicity ${ }^{[29,30]}$. The possible complications of radiotherapy for pituitary adenomas are visual damage from optic nerve or chiasmal necrosis, cranial neuropathy $(<1 \%)$, parenchymal brain necrosis $(<0.2 \%)$, pituitary apoplexy $(<1 \%)$ and second brain tumors $(0-3$ per 200,000 patients) ${ }^{[31,32]}$. However, the most common long-term complication of radiotherapy is pituitary insufficiency, with reported incidences as high as $72 \%{ }^{[31,32]}$.

Pituitary apoplexy is a clinical (rather than pathological) syndrome characterized by sudden headache, vomiting, visual impairment and meningismus caused by rapid enlargement of a pituitary adenoma usually due to hemorrhagic infarction of the tumor, originally described by Pearce Bailey in $1898^{[33]}$. Although the exact patho-physiology remains uncertain, the syndrome of apoplexy usually evolves fully within hours or two days ${ }^{[21]}$. Possible theories include, (i) rapid tumor growth with relative lack of vascular supply producing an ischemic necrosis and then hemorrhage; (ii) direct invasion of vessel wall by the tumor and consequent vessel rupture; (iii) differences in the vasculature of adenoma and the normal adeno-hypophysis; (iv) compromised blood flow caused by compression of portal vessels and the pituitary stalk; (v) high pressure system through inferior hypophyseal arteries causes hemorrhages in the low pressure adenohypophyseal sinusoids; (vi) increased intra-sellar pressure and fragile neo-vascularisation.

The cornerstones of managing pituitary apoplexy include a high degree of suspicion, appropriate investigations, endocrine replacement therapy and surgical decompression when required. A grading scale correlating the degree of sphenoid sinus thickening (on MRI) and clinical presentation (endocrine/visual abnormalities) has been proposed to guide therapy ${ }^{\text {[34] }}$. Early surgical decompression is recommended when ocular paresis and visual disturbance are present ${ }^{[35,36]}$. Rapid and early diagnosis of pituitary apoplexy allows for aggressive endocrine management and neurosurgical decompression, which decreases mortality and morbidity rates from as high as $100 \%$ to as low as $6.7 \%{ }^{[16]}$.

Radiotherapy may cause small regions of hemorrhagic necrosis in a cystic or highly vascular tumor which may resolve spontaneously or may infrequently cause sudden enlargement of the tumor resulting in patients presenting with pituitary 
apoplexy ${ }^{[21]}$. Weisberg et al (1977) looked at 14 cases of apoplexy in 300 patients with pituitary adenomas of which 8 cases were associated with conventional radiotherapy (45 Gy-50 Gy). Five cases occurred while on radiotherapy of which three occurred during the first week. The remaining three cases occurred more than three years later ${ }^{\text {[21]. Endothelial }}$ damage post SRT by induction of an inflammatory response with fibroblastic proliferation, hyalinization and scarring of vessels is known to occur ${ }^{[37-39]}$.

\section{Conclusion}

Radiotherapy as a cause of pituitary apoplexy is not well understood or documented. Endothelial damage appears to be induced by both the high treatment doses ( $>8 \mathrm{~Gy}-10 \mathrm{~Gy}$ ) of single-dose radiotherapy and also the low-dose (1.8 Gy-4 Gy) exposures of fractionated radiotherapy. Pituitary apoplexy should be suspected in a patient who develops new onset headaches and visual disturbance during or shortly after radiotherapy. It is unclear if the incidence of apoplexy is different for conventionally fractionated, HF-SRT or SRS. It is thought to occur more commonly in adenomas composed largely of cystic components, as compared to a solid adenoma. Further studies are needed to establish an optimum strategy for the management of patients with pituitary tumors who have a prior history of pituitary hemorrhage or a predominantly cystic tumor.

\section{Conflicting interests}

The authors declare that they have no conflicting interests.

\section{References}

[1] Mohr G, Hardy J. Hemorrhage, necrosis, and apoplexy in pituitary adenomas. Surg Neurol. 1982; 18: 181-9. http://dx.doi.org/10.1016/0090-3019(82)90388-3

[2] Mohanty S, Tandon PN, Banerji AK, Prakash B. Haemorrhage into pituitary adenomas. J Neurol Neurosurg Psychiatry. 1977; 40: 987-91. PMid:591978 http://dx.doi.org/10.1136/jnnp.40.10.987

[3] Tsitsopoulos P, Andrew J, Harrison MJ. Pituitary apoplexy and haemorrhage into adenomas. Postgrad Med J. 1986; 62: 623-6. PMid:3748928 http://dx.doi.org/10.1136/pgmj.62.729.623

[4] Randeva HS, Schoebel J, Byrne J, Esiri M, Adams CB, Wass JA. Classical pituitary apoplexy: clinical features, management and outcome. Clin Endocrinol (Oxf). 1999; 51: 181-8. http://dx.doi.org/10.1046/j.1365-2265.1999.00754.x

[5] Huang WY, Chien YY, Wu CL Weng WC, Peng TI, Chen HC. Pituitary adenoma apoplexy with initial presentation mimicking bacterial meningoencephalitis: a case report. Am J Emerg Med. 2009; 27: 517 e1-4.

[6] Chibbaro S, Benvenuti L, Carnesecchi S Faggionato F, Gagliardi R. An interesting case of a pituitary adenoma apoplexy mimicking an acute meningitis. Case report. J Neurosurg Sci. 2007; 51: 65-9; discussion 8-9. PMid:17571037

[7] Holness RO, Ogundimu FA, Langille RA. Pituitary apoplexy following closed head trauma. Case report. J Neurosurg. 1983; 59: 677-9. PMid:6886789 http://dx.doi.org/10.3171/jns.1983.59.4.0677

[8] Vidal E, Cevallos R, Vidal J, Ravon R, Moreau JJ, Rogues AM, et al. Twelve cases of pituitary apoplexy. Arch Intern Med. 1992; 152: 1893-9. PMid:1520058 http://dx.doi.org/10.1001/archinte.1992.00400210115020

[9] Alhajje A, Lambert M, Crabbe J. Pituitary apoplexy in an acromegalic patient during bromocriptine therapy. Case report. J Neurosurg. 1985; 63: 288-92. PMid:4020451 http://dx.doi.org/10.3171/jns.1985.63.2.0288

[10] Yamaji T, Ishibashi M, Kosaka K, Fukushima T, Hori T, Manaka S, et al. Pituitary apoplexy in acromegaly during bromocriptine therapy. Acta Endocrinol (Copenh). 1981; 98: 171-7.

[11] Nourizadeh AR, Pitts FW. Hemorrhage into Pituitary Adenoma during Anticoagulant Therapy. JAMA. 1965; $193: 623-5$. http://dx.doi.org/10.1001/jama.1965.03090070073033

[12] Savage EB, Gugino L, Starr PA, Black PM, Cohn LH, Aranki SF. Pituitary apoplexy following cardiopulmonary bypass: considerations for a staged cardiac and neurosurgical procedure. Eur J Cardiothorac Surg. 1994; 8: 333-6. http://dx.doi.org/10.1016/S1010-7940(05)80095-8

[13] Shapiro LM. Pituitary apoplexy following coronary artery bypass surgery. J Surg Oncol. 1990; 44: 66-8. PMid:2342378 http://dx.doi.org/10.1002/jso.2930440115 
[14] Yahagi N, Nishikawa A, Matsui S, Komoda Y, Sai Y, Amakata Y. Pituitary apoplexy following cholecystectomy. Anaesthesia. 1992; 47: 234-6. PMid:1566994 http://dx.doi.org/10.1111/j.1365-2044.1992.tb02128.x

[15] Brennan CF, Malone RG, Weaver JA. Pituitary necrosis in diabetes mellitus. Lancet. 1956; 271: 12-6. http://dx.doi.org/10.1016/S0140-6736(56)91387-3

[16] Cardoso ER, Peterson EW. Pituitary apoplexy: a review. Neurosurgery. 1984; 14: 363-73. http://dx.doi.org/10.1227/00006123-198403000-00021

[17] Piotin M, Tampieri D, Rufenacht DA, Mohr G, Garant M, Del Carpio R, et al. The various MRI patterns of pituitary apoplexy. Eur Radiol. 1999; 9: 918-23. PMid:10369991 http://dx.doi.org/10.1007/s003300050767

[18] Vassallo M, Rana Z, Allen S. Pituitary apoplexy after stimulation tests. Postgrad Med J. 1994; 70: 444-5. PMid:8029166 http://dx.doi.org/10.1136/pgmj.70.824.444

[19] Alatakis S, Malham GM, Fabinyi GC. Spontaneous haemorrhage into an empty sella turcica mimicking pituitary apoplexy. J Clin Neurosci. 2000; 7: 557-60. PMid:11029243 http://dx.doi.org/10.1054/jocn.2000.0722

[20] Arafah BM, Harrington JF, Madhoun ZT, Selman WR. Improvement of pituitary function after surgical decompression for pituitary tumor apoplexy. J Clin Endocrinol Metab. 1990; 71: 323-8. PMid:2166068 http://dx.doi.org/10.1210/jcem-71-2-323

[21] Weisberg LA. Pituitary apoplexy. Association of degenerative change in pituitary ademona with radiotherapy and detection by cerebral computed tomography. Am J Med. 1977; 63: 109-15. http://dx.doi.org/10.1016/0002-9343(77)90122-X

[22] Freda PU, Post KD. Differential diagnosis of sellar masses. Endocrinol Metab Clin North Am. 1999; 28: 81-117, vi. http://dx.doi.org/10.1016/S0889-8529(05)70058-X

[23] Chandler WF, Schteingart DE, Lloyd RV, McKeever PE, Ibarra-Perez G. Surgical treatment of Cushing's disease. J Neurosurg. 1987; 66: 204-12. PMid:3806203 http://dx.doi.org/10.3171/jns.1987.66.2.0204

[24] Mampalam TJ, Tyrrell JB, Wilson CB. Transsphenoidal microsurgery for Cushing disease. A report of 216 cases. Ann Intern Med. 1988; 109: 487-93. PMid:2843068

[25] Chun M, Masko GB, Hetelekidis S. Radiotherapy in the treatment of pituitary adenomas. Int J Radiat Oncol Biol Phys. 1988; 15: 305-9. http://dx.doi.org/10.1016/S0360-3016(98)90009-8

[26] Grigsby PW, Stokes S, Marks JE, Simpson JR. Prognostic factors and results of radiotherapy alone in the management of pituitary adenomas. Int J Radiat Oncol Biol Phys. 1988; 15: 1103-10. http://dx.doi.org/10.1016/0360-3016(88)90191-5

[27] Kong DS, Lee JI, Lim do H, Kim KW, Shin HJ, Nam DH,et al. The efficacy of fractionated radiotherapy and stereotactic radiosurgery for pituitary adenomas: long-term results of 125 consecutive patients treated in a single institution. Cancer. 2007; 110: 854-60. PMid:17599761 http://dx.doi.org/10.1002/cncr.22860

[28] Mitsumori M, Shrieve DC, Alexander E, 3rd, Kaiser UB, Richardson GE, Black PM, et al. Initial clinical results of LINAC-based stereotactic radiosurgery and stereotactic radiotherapy for pituitary adenomas. Int J Radiat Oncol Biol Phys. 1998; 42 : 573-80. http://dx.doi.org/10.1016/S0360-3016(98)00256-9

[29] Milker-Zabel S, Debus J, Thilmann, Schlegel W, Wannenmacher M. Fractionated stereotactically guided radiotherapy and radiosurgery in the treatment of functional and nonfunctional adenomas of the pituitary gland. Int J Radiat Oncol Biol Phys. 2001; 50: 1279-86. http://dx.doi.org/10.1016/S0360-3016(01)01535-8

[30] Witt TC. Stereotactic radiosurgery for pituitary tumors. Neurosurg Focus. 2003; 14: e10. PMid:15669806 http://dx.doi.org/10.3171/foc.2003.14.5.11

[31] Sheehan JP, Niranjan A, Sheehan JM, Jane JA Jr, Laws ER, Kondziolka D,et al. Stereotactic radiosurgery for pituitary adenomas: an intermediate review of its safety, efficacy, and role in the neurosurgical treatment armamentarium. J Neurosurg. 2005; 102: 678-91. PMid:15871511 http://dx.doi.org/10.3171/jns.2005.102.4.0678

[32] Jagannathan J, Yen CP, Pouratian N, Laws ER, Sheehan JP. Stereotactic radiosurgery for pituitary adenomas: a comprehensive review of indications, techniques and long-term results using the Gamma Knife. J Neurooncol. 2009; 92: 345-56. PMid:19357961 http://dx.doi.org/10.1007/s11060-009-9832-5

[33] Bailey P. Pathological report of a case of akromegaly, with special reference to the lesions in the hypophysis cerebri and in the thyroid gland; and a case of haemorrhage into the pituitary. Philadelphia Medical Journal. 1898; 1: 789-92.

[34] Liu JK, Couldwell WT. Pituitary apoplexy in the magnetic resonance imaging era: clinical significance of sphenoid sinus mucosal thickening. J Neurosurg. 2006; 104: 892-8. PMid:16776332 http://dx.doi.org/10.3171/jns.2006.104.6.892

[35] Kaplan B, Day AL, Quisling R, Ballinger W. Hemorrhage into pituitary adenomas. Surg Neurol. 1983; 20: 280-7. http://dx.doi.org/10.1016/0090-3019(83)90079-4

[36] Onesti ST, Wisniewski T, Post KD. Clinical versus subclinical pituitary apoplexy: presentation, surgical management, and outcome in 21 patients. Neurosurgery. 1990; 26: 980-6. PMid:2362675 http://dx.doi.org/10.1227/00006123-199006000-00010 
[37] Jagannathan J, Bourne TD, Schlesinger D, Yen CP, Shaffrey ME, Laws ER Jr, et al. Clinical and pathological characteristics of brain metastasis resected after failed radiosurgery. Neurosurgery. 2010; 66: 208-17. PMid:20023552 http://dx.doi.org/10.1227/01.NEU.0000359318.90478.69

[38] Andisheh B, Brahme A, Bitaraf MA, Mavroidis P, Lind BK. Clinical and radiobiological advantages of single-dose stereotactic light-ion radiation therapy for large intracranial arteriovenous malformations. Technical note. J Neurosurg. 2009; 111: 919-26. PMid:19392591 http://dx.doi.org/10.3171/2007.10.17205

[39] Fuks Z, Kolesnick R. Engaging the vascular component of the tumor response. Cancer Cell. 2005; 8: 89-91. PMid:16098459 http://dx.doi.org/10.1016/j.ccr.2005.07.014 